
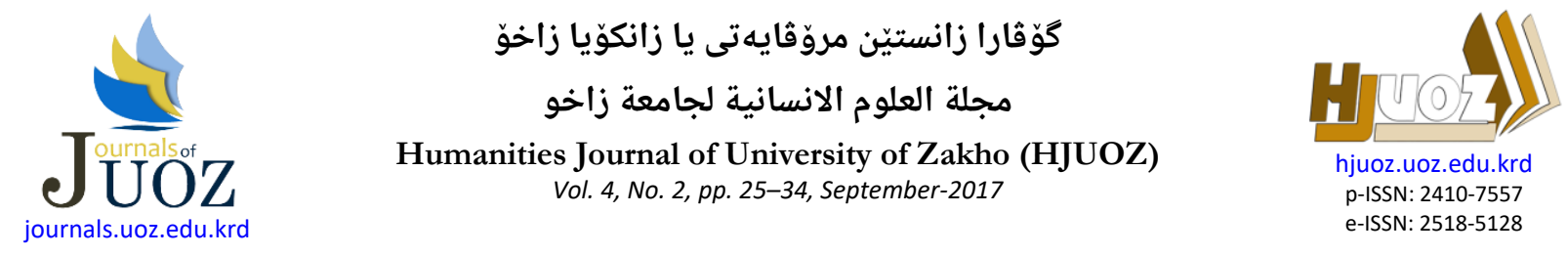

\title{
Teaching Reading and Summarising; a Lesson Focus on Reading and Summary Writing Aimed to EAP Intermediate Students
}

\author{
Shaima Ahmed Hassan \& Deman Kareem Kareem \\ Dept. of English, College of Basic Education, University of Duhok, Kurdistan region-Iraq
}

https://doi.org/10.26436/2016.4.2.403

\begin{abstract}
Academic writing has a significant role in the area of higher education, both in students' understanding of course content and the consequent assessment of students' knowledge. This research aims to present a brief overview of reading and summary writing then an evaluation of teaching materials being used in a lesson on reading and summary writing together with a detailed commentary of the lesson plan will be presented.
\end{abstract}

Keywords: Lesson plan, academic Reading \& Summary writing

\section{Introduction}

$\mathbf{M}_{\text {the role of Academic writing in the }}^{\text {any studies have been done to illustrate }}$ field of higher Education. Recent studies have highlighted the importance of teaching academic writing skills to university students (GanobsickWilliams, 2004). The term summary writing is a major aspect of academic writing and is normally linked to academic reading through note taking (johns, 1988).

This research aims to present a brief overview of reading and summary writing then an evaluation of teaching materials being used in a lesson on reading and summary writing together with a detailed commentary of the lesson plan will be presented. A certain evaluation checklist is developed for selecting materials for this lesson based on Byrd, 2001; Cunningsworth, 1995; Daoud \& Celce-Murcia 1979, Krashen, 1997; Lee, 2003; Skieerso, 1991; and Salataci \& Akyel's, 2002 work.

Since there are many materials used in this research, a brief explanation of each material has been provided before going to the evaluation point. After evaluating the materials used in this lesson plan, a detailed explanation on the rationale of choosing these materials will be highlighted. After that the teaching methods being used in exploiting these materials will be provided. Finally, a detailed commentary on designing a lesson plan will be offered.

\section{A Brief Overview of Critical Reading and Summarising}

Academic writing is very important for all students and it is considered a wide umbrella concept. There are various approaches and practice types for academic writing. These approaches depend on different issues such as the purpose and type of writing, or they simply depend on personal preference (Jordan, 1997). Moreover, academic writing is used to express learned knowledge in a particular subject area. It is mainly assumed for learning development, or for course assessment purposes and the same principles apply to publication of academic papers (Britton, 1979). Internationally, academic writing and its theories are evident or understandable in Australia, South Africa and Northern Europe; however the United States has developed substantially in this field. Institutions in America started providing their students with writing support since the late of the Nineteenth Century (Ibid). In response, developments and theories in academic writing discussed and published in the United States since 1960s (Grabe and Kaplan, 1996). Consequently, Britain started providing their students with writing support between 1967 and 1974 (Jordan, 1997).

It was recognised long time ago that both reading and writing are closely integrated skills and are linked to each other (Krashen, 1984). This integration is considered as a fundamental characteristic of the target academic situation in which students normally read books and articles, take notes, summarise, and then start writing their essays and theses. In the real practice the link between reading and writing is normally involved. Though, in some cases the focus might be on several reading strategies and skills such as skimming, scanning, and predicting and then the resulting exercises usually involve writing 
(Jordan, 1997). Reading for academic purposes is a complex subject. However, there is always a basic feature which is reading for a purpose. Reading for a purpose could be the starting point for other considerations. Obviously, there are many different reasons and purposes behind students' reading, such as to get information, to understand some ideas and theories, to realise the authors' different views or to seek for some evidence (ibid). Reading to write tasks have been widely observed in many university settings. An example of reading to write tasks is summarising which has been defined as 'the process of synthesising and organising individual idea units in to a summary or organised series of related general ideas' (Irwin, 1986, pp.5). Julley (1994) believes that summary writing depends on two important skills: first, the ability to read the text with the whole understanding; second, the ability to write down what has been read shortly. $\mathrm{He}$ also adds that since writing summary depends on a clear understanding of the text, there is a need for accurate note taking. Casazza (1993) states that to write a good summary, one needs to be able to understand the whole text, select the most important information, reduce the minor and redundant details, combine similar ideas in to categories and write on their own words.

\subsection{Materials Used in the Lesson and the Rationale for their Selection}

According to McGrath (2002), materials have a wide sense; they could be real objects such as pencil, board, projector etc. which can be exploited successfully for the process of language learning, or they could be paper-based materials such as textbooks, handouts, computer software, articles and recordings which have been specially chosen for teaching and learning by either the classroom teacher, teacher-written materials or learner generated materials.

Material evaluation, on the other hand, is a way which implies measuring the value of materials. It also covers making judgments about the influence of the materials on students, teachers, and the administrators who will be using them. Material evaluation also tries to measure the materials according to reliability, credibility and validity (Tomlinson, 2003). Furthermore, two main factors should be taken into account in selecting and evaluating materials which are the effectiveness and the appropriateness of the materials in order to achieve the aim and the purpose of the course for learners and teachers (Grave, 1996). Another important point has been mentioned by Swain 1985 regarding materials, that they should give learners the chance to use the target language to achieve communication purpose in the classroom.

Before selecting materials, the teachers should use specific selecting criteria. Therefore, for this lesson an evaluation checklist has been designed as a criterion for selecting materials based on Cunningsworth, 1995; Byrd, 2001; Skieerso, 1991; Lee, 2003; Krashen, 1997; Salataci \& Akyel, 2002; and Daoud \& CelceMuricia's, 1979 work (see Appendix 2). The checklist covers three main points: the first point focuses on the language content which measures the extent to which the contents of the materials are appropriate for the learners specially the vocabulary which should be evaluated clearly in order to make materials understandable for learners. The second point concentrates on the context of the materials and the extent to which materials are suitable, integrated, interesting and organised for the learners. The final point focuses on the methods and approaches that are followed by the teachers to present and teach the materials.

The materials that have been used for this lesson plan for practicing summarising skills consist of one text and two handouts related to the topic. The hand-outs give students instructions on how to read and write their summary. It is also worth mentioning that all selected materials are from the Centre for English Language Education (CELE) at the University of Nottingham/United Kingdom. This gives the materials more accuracy, reliability, and validity.

Three materials for this research have been chosen according to the aims of the lesson. The content of the materials includes useful hand outs. The first handout (See Appendix 3/1) presents a brief explanation about summarising, its definition and structure. This hand out introduces the learners to the term summary, the information that should be included in a summary and how the summary is different from the original work. While the second hand out (See Appendix 3/2) covers the main steps of writing summary. This handout is important as it enables learners to follow certain steps to summarise a text. The final handout is a text which is also taken from CELE. In this handout students are required to read and summarise the text. 


\subsection{Methodology Used for Exploitation of the Materials}

\subsubsection{General Approach}

For the purpose of this research and for the organisation of materials in the lesson plan, a task-based approach has been developed. The task-based approach was first developed in India by N. S. Prabhu in the 1980s. The nature of this method is that when students are given a task, they engage in groups and start to discuss the text with the group's members in order to select important information and to understand the text. The term task refers to an activity where the target language is used by learners for communicative purpose in order to achieve an outcome (Willis, 2002). In addition, Nunan (2006) illustrated that tasks have non-linguistic results, then he defines task as a piece of classroom activity that requires learners in comprehending, producing, and progressing their skills in the target language while their focus is on meaning rather than on form.

Moreover, Willis (1996) found that the framework of the task based approach can be divided into four phrases: pre-task, task, taskcycle, and language focus (post-task). Pre -task provides the introduction of the topic to learners under the teacher's guidance. The teacher makes students memorise and/or write words and phrases from pre-task activities. In the task-cycle students get opportunity to express their ideas and communicate with other learners while doing the task by using the language that they already know. Most of the time learners do the task in pairs or small groups and prepare to represent their performance to the whole class by reporting what they have done. Task-based approach also suggests using tasks as a key element in the language classroom because they offer the best context for learners to activate their process of acquiring the target language (Shehadeh, 2005). Larsen Freeman (2000) mentions the advantages of task based approach because it provides opportunities for students to interact frequently in groups.

Due to the materials that have been selected for the purpose of this research, task-based approach is considered as a main method of teaching this lesson as it gives the learners opportunities to interact and communicate with each other collaboratively through working in groups or in pairs by doing some activities such as problem solving, sharing opinions, transferring and selecting information or task completion activities. A detailed explanation of such activities will be presented in 3.1.

\subsubsection{Supplementary Approach}

There are three main approaches for academic writing which are process approach, product approach and genre-based approach. In this research the genre-based approach has been followed to teach and enhance students' summarisation abilities. Hyland (2007) defines genre as a group of texts which share similar discoursal aspects that are easily recognised by members of a community. Sidaway (2006) used the term 'the magnificent seven' to classify genre into: recount, narrative, explanation, information report, procedure, discussion and exposition. Each genre may present itself in various text forms.

Based on Halliday's (1994) Systemic Functional Linguistics, a genre-based approach for teaching L2 writing focuses on the conventions of a particular text type and it helps students to understand the purpose of their writing, the audience, and the organization of the text. Furthermore, Hyland (1994) believes that genre-based writing instruction has significant emphases on scaffolding and collaboration.

In some empirical studies the role of genre based approach has been shown as an approach which helps to enhance the students' ability in constructing narrative, expository, and argumentative essays. Therefore, it is assumed that this approach might similarly benefit students' summarisation performance. If students have a clear understanding of how a source text is structured, it would be easier for them to differentiate between major and minor points and to create ideas in a more active way (Kongpetch, 2006 and Cheng, 2008).

\section{Lesson Plan}

\subsection{Lesson Description}

The lesson plan in this paper is designed for 12 intermediate students (6 from Iraq, 3 from China, 2 from Saudi Arabia, and 1 from Japan) as a group of students studying at Centre of English language education in the University of Nottingham. The purpose behind this lesson is to help students write an assignment of 1000-1500 words about "students' life in Nottingham". This lesson plan is based on two main approaches: first, task-based approach as a general approach which helps students to interact with each other in groups while doing activities; second, genrebased approach as a supplementary approach which enhances students' ability in writing a 
summary. Also the purpose behind designing this lesson plan is to improve students' ability in both reading and summarising skills. The lesson plan consists of eight stages: introduction, introducing summarising steps, handing in text stage, reading and discussion, highlighting vocabulary, creating ideas, writing key words and finally writing a summary.

In the introduction the teacher starts the lesson by introducing the students to the topic of the lesson, namely reading and summary writing, by providing a handout (see Appendix 2/1) which covers a brief explanation of summery writing. Then the teacher will ask them to look at the handout and to work on the answers together. Based on Sidaway (2006), the purpose of this handout is to introduce summary to the learners and give them a brief explanation, information, and discussion about summarising.

Introducing summarising steps basically is a second practice stage in which the teacher will provide students with another handout (see Appendix 2/2) which covers the steps of writing a summary, and then will give them time to take a look at the steps and read them carefully. based on both Hyland, (1994) and Widod's, (2006) views, the purpose behind selecting this material is to enable students to understand the purpose and the procedures of writing summary and the organisation of each step.

Once students have covered the steps of writing summary, the emphasis on the text stage will start. The teacher will give them the text (see Appendix3/3) to read and do the above procedures and steps. This stage is more prominent in the product or genre approaches to writing, and will help to raise students' awareness of the conventions of typical tasks of different genres. Before reading the text, the teacher will start asking the students some questions regarding the text which include some questions about the topic and the name of the author. The purpose behind this is to raise students' awareness of the referencing, to identify the features and the language they have in common, to raise their awareness of the features of the text and to provide them with expressions they can use in their own writing.

Once students get enough information about the text, the teacher will move to the next stage which is giving learners time to discuss the task together in groups. According to Heller, Keith and Anderson (1991) working collaboratively in groups helps students to learn complex skills through sharing their ideas and knowledge as they solve a problem together. Individual group members can also learn explanation and justification from one another. Students learn more about what they were taught when they are actively involved in groups; they will also be more satisfied with their work (Johnson, Johnson, and Smith, 1991).

After having the students discuss the task among themselves, the teacher will move to writing down the key vocabulary of the text on the board. The purpose behind this activity is to make sure that the students understand the meaning of the key vocabulary in the text based on cunningsworth's checklist (1995).

Once key vocabulary have been highlighted, the teacher will ask the learners to go through the steps of writing the summary again and read the text, then select the main ideas and supporting ideas from the text. This stage will help them discover the main ideas of the text. Here students practise an academic reading strategy which is skimming for the main ideas. Then, the teacher will ask them about the topic sentences and supporting information or the examples; by doing this the teacher will make sure whether they have selected the right information from the text or not. Here the importance of reading and selecting information is highlighted. As mentioned in the previous section, there are many reading skills books that focus on reading for information so they always give practice to various strategies such as skimming scanning and prediction (Jordan, 1980 and Wallace, 1980). After choosing the main information from the text, the learners will work in pairs to compare, transfer and share their ideas together. To make sure that the whole class get the required information, main ideas and supporting ideas, the teacher will ask them questions related to the text in order to make sure that they have the right information. Pair work is considered as an effective technique which lets the learners share opinions and information together in a stress free environment (Brumfit, 1984).

After checking the information, the teacher will ask the students to write down the key vocabulary of the text. This stage will enable learners to think and write key words and ideas about the text.

Finally, the teacher will ask them to transfer the key words and ideas to a summary of the text. Before starting to write the summary, the teacher should advise the students to use linking words to link the main ideas together. Also 
reminding them about paying attention to the grammatical and sentence structure will be helpful. Then the teacher will give them time to write the summary. The purpose of this stage is to raise the students' awareness of integrating the two skills together through transferring the ideas and key words which have been chosen from the text and write them as a summary as based on Cunningsworth's 1995 checklist.

\section{Conclusion}

Both reading and summary writing are two integrated skills that play an important role in different types of genres. Text summarising represents an important writing genre. The ability to critically read the passage and summarise it is an essential language skill. EAP students are often frightened of summary tasks for EAP texts. However, if the summarising skill is taught systematically, and reading skill also developed, the task of summarising texts will become less confusing.

The purpose behind creating this lesson was to help the learners to be able to read different texts critically and then write a summary about a related text named, 'Students life in Nottingham'.

\section{References}

Byard, P. (2001). Textbooks: Evaluation and selection and analysis for implementation. In CelceMuricia, M. Teaching English as a second or foreign language, $3^{\text {rd }}$ ed. Boston: Heinle \& Heinle.

Brumfit, C. (1984). Communicative methodology in language teaching: the roles of fluency and accuracy. Cambridge: Cambridge University Press.

Britton, J. (1970). Language and Learning. New York. Penguin.

Cunningsworth, A. (1995). Choosing Your Coursbook. Oxford: Heinemann.

Cheng, F. W. (2008). Scaffolding language, scaffolding writing: a genre approach to teaching narrative writing. Asian EFL Journal 10(2): 167-911.

Casazza, M. E. (1993). Using model of direct instruction to teach summary writing in a college reading class. Journal of Reading. 37(3): 202-8.

Daoud, A. M. \& Celce-Muricia, M. (1979). Selecting and evaluating textbooks. In Celce-Moricia, M. \& McIntosh, L. Teaching English as a second or foreign language. New York: Newbury House.

Grabe, W. And Kaplan, R. (1996). Theory and practice of writing. London. Longman.

Granobscik-Williams, L. (2004). A Report on the Teaching of Academic Writing in UK Higher Education. University of Warwick. Unpublished research project.
Haliday, M. K. 1994. An introduction to functional Grammar. London: Edward Arnold.

Hyland, K. (1994). Hedging in Academic writing and EAP textbooks. English for specific purposes, 13(3).

Hyland, K. (2007). Genre pedagogy: language, literacy and L2 writing instruction. Journal of second language writing 16 (3): 148-64.

Heller, Keith, and Anderson. (1992). Teaching problem solving through cooperative grouping. Am. J. Physics. 60(7): 627-636.

Irwin, J. (1986). Teaching Reading Comprehension Processes. Englewood Cliffs, NJ: Prentice-Hall.

Jolly, D. (1994). Writing Tasks. Cambridge: Cambridge University Press.

Johns, A. M. (1988). Reading for summarising: an approach to text orientation and processing. Reading in a foreign language, 4(2).

Jordan, R. R. (1980). Looking for information. London: Longman.

Jordan, R. R. (1997). What's in a name? English for specific purposes, 16 (1).

Johnson, D. W., Johnson, R. T., and Smith, K. A.1991. Cooperative Learning: Increasing College Faculty Instructional Productivity. ASHE-FRIC Higher Education Report No.4. Washington, D.C.: School of Education and Human Development, George Washington University.

Kongpetch, S. (2006). Using a genre-based approach to teach writing to Thai students: a case study. Prospect 21(2): 3-33.

Krashen, S, d. (1984). Writing: Research, Theory, and Application. Oxford: Pergamon.

Krashen, S. (1997). Does free voluntary reading lead to academic language? Journal of intensive English studies, 11, 1-18.

Larsen-Freeman, D. (2002). Techniques and principles in language teaching. Oxford: Oxford University Press.

Lee, J.F. \& VanPatten, B. (2003). Making communicative language teaching happen. Boston: McGraw-Hill.

McGrath, Ian. (2002). Materials Evaluation and Design for Language Teaching. Edinburgh: Edinburgh University Press.

Nunan, D. (2006) Task-Based Language Teaching in the Asia context: Defining 'task'. Asian EFL Journal 8:3: 12-18.

Skierso, A. (1991). Textbook selection and evaluation. In Celce-Muricia, M. Teaching English as a second or foreign language, Boston: Heinle \& Heinle.

Salataci, R. \& Akyel, A. (2002). Possible effects of strategy instruction on L1 and L2 readding. Reading in Foreign language, 14(1), 1-17.

Sidway, R. (2006). The genre-based approach to teach writing. In English! Spring issue: 24-7. 
Shehadeh, A. (2005). Task-based Language Learning and Teaching: Theories and applications. In Edwards, C., and Willis, J. (eds.) 2005. Teachers Exploring Tasks in English Language Teaching. Palgrave Macmillan.

Swain, M. (1985). 'Communicative Competence: some roles of comprehensible input and comprehensible output in its development' in S. Gass and C. Madden (eds) Input in Second Language Acquisition. Rowley, MA: Newbury House.
Tomlinson, B. (2003). Developing materials for language teaching. London: Continuum.

Wallace, M. J. (1980). Study Skills in English. Cambridge: Cambridge University Press.

Willis, J. (1996). A Framework for Task-Based Learning. Harlow: Longman.

Willis, J. 2002. What English do primary Teachers need? JALT Language Teacher, 26(7).

الخلاصة.

الكتابة الاكاديمية لها دورا مهما في التعليم العالي وتتضمن جاتبين مهمين وهما الدراية بمضمون الكورس وتقييم مستوى

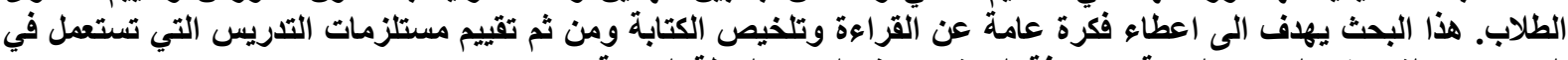

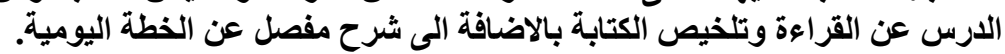




\section{Appendixes \\ Appendix 1 \\ A practical lesson plan on Reading and summarizing practice}

Time: 1.5 hour

Guiding constructs: Reading and Summary Writing.

Teacher's aims:

- To introduce the students to the process of reading and summary writing.

- To lead them practice skills of reading and summary writing.

Materials:

- Handout 1 , main ideas on summary writing

- Handout 2, steps of writing summary.

- Handout 3, text on culture.

Aids

- Projector and whiteboard

Target Students' level: Intermediate

Lesson Description

\begin{tabular}{|c|c|c|c|}
\hline Stage \& Material & $\begin{array}{l}\text { Aim } \& \quad \text { target } \\
\text { language }\end{array}$ & Procedures & $\begin{array}{l}\text { Participant } \\
\text { structure \& time }\end{array}$ \\
\hline $\begin{array}{l}\text { Introduction reading } \\
\text { and summary writing. } \\
\text { Hand out } 1\end{array}$ & $\begin{array}{l}\text { Introduce the reading } \\
\text { and } \\
\text { process }\end{array}$ & $\begin{array}{l}\text { T. introduces the } \\
\text { students to the topic, its } \\
\text { importance to writing an } \\
\text { assignment and the aims } \\
\text { of the lesson. }\end{array}$ & Whole class, 3 mins. \\
\hline $\begin{array}{l}\text { Presentation: steps } \\
\text { for writing a } \\
\text { summary handout } 2\end{array}$ & $\begin{array}{l}\text { Process explanation } \\
\text { and description in the } \\
\text { handout to enable } \\
\text { students to be familiar } \\
\text { about the reading, and } \\
\text { summary writing } \\
\text { process. }\end{array}$ & $\begin{array}{l}\text { T. gives detailed } \\
\text { explanation about steps } \\
\text { to read, write down key } \\
\text { words, and write a } \\
\text { summary with students. } \\
\text { T. Advises them to read } \\
\text { carefully and distinguish } \\
\text { main ideas and the } \\
\text { supporting information. } \\
\text { T. explains how to take } \\
\text { key words without } \\
\text { looking at the handout. }\end{array}$ & Whole class 15 mins. \\
\hline $\begin{array}{l}\text { Hand out the text to } \\
\text { students. Handout } 3\end{array}$ & $\begin{array}{l}\text { To draw the students' } \\
\text { attention to the } \\
\text { referencing of the text. }\end{array}$ & $\begin{array}{l}\text { T. starts asking students } \\
\text { about the key words in } \\
\text { the text; the name of the } \\
\text { author and the } \\
\text { specialization etc... }\end{array}$ & Whole class 8 mins. \\
\hline Reading discussion & $\begin{array}{l}\text { To make sure how } \\
\text { much the students } \\
\text { know about the topic. }\end{array}$ & $\begin{array}{l}\text { T. asks the students to } \\
\text { discuss in pairs how } \\
\text { much information they } \\
\text { have about the topic. }\end{array}$ & In pairs 6 mins. \\
\hline $\begin{array}{l}\text { Highlighting } \\
\text { vocabulary }\end{array}$ & $\begin{array}{l}\text { To make the students } \\
\text { understand the main } \\
\text { vocabulary and } \\
\text { message point before } \\
\text { reading the text. }\end{array}$ & $\begin{array}{l}\text { T. writes down the key } \\
\text { vocabulary on the board } \\
\text { and clarifies information } \\
\text { from students: } \\
\text { sociologist, signs, } \\
\text { worldviews, artefacts, } \\
\text { non-material culture, } \\
\text { customs, values, } \\
\text { customs, and beliefs. }\end{array}$ & Whole class 8 mins. \\
\hline
\end{tabular}




\begin{tabular}{|c|c|c|c|}
\hline $\begin{array}{l}\text { Reading the text and } \\
\text { selecting main ideas }\end{array}$ & $\begin{array}{l}\text { To let the students skim } \\
\text { the main ideas and } \\
\text { supporting ideas from } \\
\text { the text. }\end{array}$ & $\begin{array}{l}\text { T. together with students } \\
\text { read the previous steps in } \\
\text { the handout. T. guides } \\
\text { students and sets a time. }\end{array}$ & $\begin{array}{l}\text { Individual work } 6 \\
\text { mins. }\end{array}$ \\
\hline Eliciting information & $\begin{array}{l}\text { To make the students } \\
\text { know the main ideas } \\
\text { and supporting ideas in } \\
\text { the text. }\end{array}$ & $\begin{array}{l}\text { T. asks students about } \\
\text { the main and support } \\
\text { ideas in the text }\end{array}$ & Whole class 8mins. \\
\hline Ensure information & $\begin{array}{l}\text { To help them know } \\
\text { whether they chose the } \\
\text { right information or } \\
\text { not. }\end{array}$ & $\begin{array}{l}\text { T. asks them to work in } \\
\text { pairs and compare their } \\
\text { notes with each other. }\end{array}$ & In pairs $6 \mathrm{mins}$ \\
\hline $\begin{array}{l}\text { Asking questions } \\
\text { based on the text }\end{array}$ & $\begin{array}{l}\text { To check whether they } \\
\text { have the right answer } \\
\text { or not. }\end{array}$ & $\begin{array}{l}\text { T. asks students main } \\
\text { questions to know how } \\
\text { much they understand } \\
\text { the text. }\end{array}$ & Whole class 5 mins \\
\hline Writing key words & $\begin{array}{l}\text { To let them write down } \\
\text { the key words, ideas } \\
\text { from the text. }\end{array}$ & $\begin{array}{l}\text { T. deduces what has been } \\
\text { done. T. asks students } \\
\text { to write their key words } \\
\text { based on main ideas. T. } \\
\text { limits the time between } \\
2-3 \text { mins. }\end{array}$ & Whole class 5 mins. \\
\hline writing summary & $\begin{array}{l}\text { To check the students } \\
\text { accuracy in writing key } \\
\text { words. }\end{array}$ & $\begin{array}{l}\text { T. asks them to start } \\
\text { writing summary. }\end{array}$ & Whole class 20 mins. \\
\hline
\end{tabular}

\section{Appendix 2}

Material evaluation checklist

I. Language content
- Is the subject presented topically or functionally in a logical, organized matter? ( Byrd, 2001 \& Skieerso, 1991)

-Does the text deal with the structure of language use such as; how to communicate, how to structure a piece of writing, how to identify the main ideas in reading passage? (Cunningsworth, 1995, pp. 3-4)

- Are new vocabulary words selected from the text and presented at an appropriate way in order to make the text understandable?(ibid)

- Are there any task-based interactive activities among the learners? ( Byrd, 2001 \& Skieerso, 1991)

- Is there material for integrated skills? (Cunningsworth, 1995, pp. 3-4)

- Is the text interesting enough that students will enjoy reading it? (Krashen, 1997)

- Are writing activities suitable in terms of accuracy, guidance/control, organizing of longer pieces of writing, and using a suitable style. (Cunningsworth, 1995, pp. 3-4)

2- Methodology

- Do teachers provide techniques for activating student's background knowledge before reading the text?(Lee, 2003)

- Do teachers provide students with examples of how to preview, skim, scan, summarise and finding the main idea?( Salataci \& Akyel, 2002) 


\begin{tabular}{|c|c|}
\hline & $\begin{array}{l}\text { - Does the material include any advice, help or } \\
\text { learning strategies on studying skills? } \\
\text { (Cunningsworth, 1995, pp. 3-4) } \\
\text {-Are students expected to take a degree of } \\
\text { responsibility for their own learning? (ibid) } \\
\text {-What approaches/approach to language learning } \\
\text { is taken by the textbook? Is this appropriate to the } \\
\text { learning/teaching situation? (ibid) } \\
\text { - How are the skills taught? (ibid) }\end{array}$ \\
\hline 3- Context & $\begin{array}{l}\text { - Is the text match with the lesson aims? (Byrd, } \\
2001 \text { \& Skieerso, 1991) } \\
\text { - Does the text appropriate for the students who } \\
\text { will sue it? (ibid) } \\
\text { - Are the examples and discussion } \\
\text { understandable? (Byrd, 2001) } \\
\text { - will the content meet the students need for } \\
\text { learning language?( Daoud \& Celce-Murcia, } 1979 \\
\text { \& Byrd, 2001) }\end{array}$ \\
\hline
\end{tabular}

\section{Appendix 3/1}

Handout about Reading and summary writing taken from Centre for English Language Education at the University of Nottingham

\section{Reading and Summary Writing}

\section{Explanations: Summaries}

What is Summary?

A summary is a brief short review of a piece of written material. It should always be shorter than the original larger work you are summarising.

What kinds of information should be in a summary?

A summary should include only main ideas and important supporting information. It shouldn't include detail or any personal opinions.

How is a summary the same as the original work?

A summary should have the basic meaning as the original work. In other words, the summary shouldn't have new or different information that is not in the original work.

How is the summary different from the original work?

A summary should not include many of the exact words as the original work. The writer should use his or her own words in the summary to express the same general ideas found in the original work.

\section{Appendix 3/2 \\ Handout about Steps for Writing a Summary taken from Centre for English Language Education/University of Nottingham}

The following steps will help you when you summarise:

1. First, read the original work you are going to summarise and find the main idea(s)

- If you are summarising a paragraph, find the topic sentences and then the main supporting ideas of that paragraph.

- If you are writing an essay, find the thesis statement and topic sentence and then the main supporting ideas of that paragraph.

- If you are summarising a large work, find the main ideas and main support. For example, in addition to looking for topic sentences $\mathrm{n}$ the paragraphs, you may want to look for chapter titles, headings and/or subheadings in the longer work.

2- Write down a few key words or phrases to help you remember the main ideas as you write the summary 
- You may also want to write a brief outline of the main ideas in the same order as they appear in the original work.

- However, don't write too much or use full sentences. Be sure to write only words or short phrases in your outline. This way you can make sure the summary working is not exactly the same as the original working.

\section{3- Begin writing your summary}

- Try not to look at the original while writing the summary. If you do that, it will be too late easy to copy the original words or phrases.

\section{Appendix 3/3 \\ Handout about specific text for summarising. Taken from Centre for English Language Education/University of Nottingham}

\section{Summarise the following text:}

"The word culture appears frequently in the media and in the academic texts. We read about cultural events, traditional values, youth culture, cultural values and cultural differences. What is culture? To socialist, culture refers to the systems of signs, meanings, and worldviews of particular group of human beings. It is everything that the members of a group learn to do, think, use, and make as a part of growing up in the group. Culture in this sense has two levels: material and nonmaterial. Material culture refers to all objects, or artefacts, that have meaning to the members of society or group, or that are used by them. Artefacts include tools, clothes, buildings, weapons, and art objects. Non-material culture, on the other hand, refers to the customs, behaviours, beliefs, values, attitudes, knowledge and language of a society"

(Adapted from Alex Thio, Sociology: A Brief introduction, 1997 (pp 40-41)) 